\title{
Nilai Budaya dan Gaya Komunikasi Warga Minangkabau, Jawa, dan Bugis
}

\author{
Pawito', Widodo Muktiyo $^{2}$, Hamid Arifin ${ }^{3}$ \\ 1,2,3 Program Studi Ilmu Komunikasi, Fakultas Ilmu Sosial dan Ilmu Politik, Universitas Sebelas Maret \\ Jl. Ir. Sutami 36A, Kentingan Jebres Surakarta, 57126, Indonesia \\ Email: pawito_palimin@staff.uns.ac.id ${ }^{1 *}$; muktiyo@yahoo.com²
}

\begin{abstract}
This study aims to analyze the communication styles developed in the Minangkabau, Javanese, and Bugis communities. This research uses qualitative methods of data collection techniques in-depth interviews (in-depth), observation (observation), documentation, and literature. Interviews and observations were carried out in three important cities: Padang (to examine the communication styles of the Minangkabau community), Surakarta (to examine the communication styles of the Javanese people), and Makassar (to examine the communication styles of the Buginese people). The results of this study describe the style of communication developed in the Minangkabau, Javanese, and Bugis communities by emphasizing four aspects: (a) the tendency to use nouns or verbs (nouniness and verbiness), (b) the use of passive or active sentences, (c) the use of direct or indirect ways of expressing ideas, and (d) the use of words or sentences when you find yourself having different positions of opinion or views with other people who are partners in conversation. The differences in the four aspects of communication style can be assessed as an implication of the culture of the three Minang, Javanese, and Bugis communities.
\end{abstract} Keywords: Culture; Communication Style; Minangkabau People; Javanese Society; The Bugis Community.

\begin{abstract}
Abstrak
Penelitian ini bertujuan menganalisis gaya komunikasi yang berkembang di masyarakat Minangkabau, Jawa, dan Bugis. Penelitian ini menggunakan metode kualitatif teknik pengumpulan data wawancara mendalam (in-depth), pengamatan (obsevasi), dokumentasi, dan literatur. Wawancara dan observasi dilakukan di tiga kota penting: Padang (untuk mencermati gaya komunikasi masyarakat Minangkabau), Surakarta (untuk mencermati gaya komunikasi masyarakat Jawa), dan Makassar (untuk mencermati gaya komunikasi masyarakat Bugis). Hasil peneltian ini mendeskripsikan gaya komunikasi yang berkembang di masyarakat Minangkabau, Jawa, dan Bugis dengan memberikan titik berat pada empat aspek: (a) kecenderungan dalam penggunaan kata benda atau kata kerja (nouniness and verbiness), (b) penggunaan kalimat pasif atau aktif, (c) penggunaan cara pengutaraan gagasan secara langsung (direct) ataukah tidak langsung (indirect), dan (d) penggunaan kata-kata atau kalimat ketika mendapati diri berbeda posisi pendapat atau pandangan dengan orang lain yang menjadi partner dalam berbincang. Perbedaan di keempat aspek gaya komunikasi tersebut dapat dinilai sebagai implikasi dari kebudayaan dari ketiga masyarakat Minang, Jawa dan Bugis. Kata kunci: Kebudayaan; Gaya Komunikasi; Masyarakat Minangkabau; Masyarakat Jawa; Masyarakat Bugis.
\end{abstract}

\section{Pendahuluan}

Indonesia memiliki kemajemukan kelompok etnis terkait adanya kebudayaan. Kemajemukan masyarakat Indonesia ditandai oleh beragam masyarakat dan kebudayaan termasuk misalnya ada kelompok masyarakat dan/atau kebudayaan Jawa, Aceh, Minangkabau, Bugis, Dayak, Maluku dan Papua. Kondisi demikian meniscayakan perawatan untuk mewujudkan harmoni dan integrasi demi terbinanya kehidupan bermasyarakat dan bernegara dalam suatu wadah Negara Kesatuan Republik
Indonesia (NKRI). Dari perspektif komunikasi, dapat dikatakan bahwa upaya merawat integrasiharmoni membutuhkan paradigma yang lebih bersifat konvergensif di antara para pelibat di kalangan masyarakat baik di tingkat kolektif maupun jalinan hubungan antar pribadi. Jalinan komunikasi yang berparadigma konvergensi membutuhkan pemahaman yang memadai mengenai kebudayaan masyarakat yang berbeda-beda termasuk gaya komunikasi dari masing-masing masyarakat atau kebudayaan bersangkutan, inilah menjadi urgensi penelitian. 
Gaya komunikasi (communication style) merupakan cara dengan mana seseorang berinteraksi dan bertukar informasi dengan orang lain. Setiap individu menjalani kehidupan bermasyarakat bersama dengan orang lain dan karenanya menjadi warga atau bagian dari kelompok masyarakat di dalam mana orang bersangkutan berada (Karell, 2018). Pemahaman mengenai gaya komunikasi sangat diperlukan dalam jalinan komunikasi untuk menuju harmoni hubungan; baik hubungan internal di antara sesama warga kelompok masyarakat maupun hubungan dengan orang atau warga dari kelompok masyarakat lain. Jalinan komunikasi terjadi antara orang dari masyarakat atau budaya yang satu (misalnya masyarakat Jawa) dengan orang dari masyarakat lain (misalnya masyarakat Minangkabau atau Bugis). Arti penting dari komunikasi adalah tercipta pemahaman bersama (mutual understanding) untuk tindakan bersama (mutual action) dalam jalinan komunikasi yang bersifat konvergen.

Nilai-nilaikebudayaanyangmelatarbelakangi orang yang terlibat dalam jalinan komunikasi harus diperhatikan. Dengan pemahaman yang memadai, diharapkan adanya saling pengertian, dapat dikurangi atau dihindari kesalahpahaman (misunderstanding) dan/atau salah persepsi (misperception). Hal ini urgen untuk membantu memperkokoh harmoni dan persatuan nasional. Harmoni dan persatuan mensyaratkan adanya saling pengertian dan saling memahami di antara individu dan/atau masyarakat dengan latarbelakang kebudayaan yang berbeda-beda.

Konsep kebudayaan merupakan konsep yang tidak mudah untuk didefinisikan. Hal demikian dikarenakan adanya banyak sekali kalangan peneliti menggunakan konsep ini dengan pemahaman masing-masing sesuai dengan bidang keilmuan yang ditekuni. Dari kalangan ilmu antropologi, misalnya, konsep kebudayaan sering dimaknai sebagai perangkat perilaku manusia yang terwariskan dari suatu generasi ke generasi berikutnya. Dalam kaitan ini pewarisan yang dimaksud tidak selalu dilakukan secara sengaja dengan tujuan tertentu secara sistematis namun bersifat alamiah seperti misalnya yang banyak sekali terjadi ketika generasi yang lebih muda berinteraksi dengan orang-orang dari generasi yang lebih tua atau sebaliknya. Menurut Cloud (2013), kebudayaan merupakan "....sets of human behavior that are passed down from one generation to the next. This transmission of culture isn't always purposeful, and may take place anywhere that young people can interact with older people."

Para peneliti terdahulu seperti Taylor seorang antropolog Inggris 1832-1917 - (Prinz, 2011) menggunakan konsep kebudayaan (culture) sebagai "the full range of learned human behavior patterns" yang kompleksitas cakupannya termasuk hal-hal seperti “.... knowledge, belief, art, law, morals, custom, and any other capabilities and habits acquired by man as a member of society." Antropolog generasi berikutnya seperti Geertz (Prinz, 2011) membahas kebudayaan dengan memberikan penekanan pada persoalan pola-pola transmisi bersifat historis mengenai makna-makna yang terkemas dalam berbagai bentuk simbol; atau dalam kata-kata Geertz kebudayaan notabene adalah: “.... an historically transmitted pattern of meanings embodied in symbols." Definisi lain dari Malinowski (Prinz, 2011) mengatakan bahwa kebudayaan merupakan “.... a well organized unity divided into two fundamental aspects-a body of artifacts and a system of customs." Definisi dari Malinowski ini memberikan penegasan mengenai dua sifat dari kebudayaan yakni artifak (mewujud secara fisik) dan non-artifak (tidak mewujud secara fisik) berupa nilai serta kebiasaan-kebiasaan, dan dapat diamati melalui perilaku serta praktik kehidupan masyarakat sehari-hari. Koentjaraningrat (1974) merupakan perintis ilmu antrologi di Indonesia, mengemukakan bahwa konsep kebudayaan, terutama bagi kalangan ilmu sosial, memiliki cakupan arti yang juga sangat luas yakni meliputi 
"seluruh total dari pikiran, karya, dan hasil karya manusia ....."Menurut Koentjaraningrat, terdapat tujuh aspek kebudayaan (Koentjaraningrat menyebutnya sebagai unsur-unsur): (1) Sistem religi dan upacara keagamaan, (2) Sistem dan organisasi kemasyarakatan, (3) Sistem pengetahuan, (4) Bahasa: suatu aspek yang paling dekat dengan komunikasi serta gaya komunikasi, (5) Kesenian, (6) Sistem mata pencaharian hidup, dan (7) Sistem tehnologi dan peralatan.

Konsep komunikasi kerapkali dipahami sebagai proses jalinan hubungan interaksi antar manusia dengan menggunakan lambanglambang atau simbol termasuk dan terutama adalah lambang-lambang bahasa. Proses jalinan yang dimaksud melibatkan setidaknya dua pihak partisipanyangsaling bertukar lambing atau pesan antara komunikator (pemrakarsa penyampai pesan) dan komunikan (penerima pesan); dengan pengertian terdapat pergantian peran di antara keduanya dalam suatu jalinan komunikasi dan/atau interaksi sosial yang berproses dalam sistem sosial dengan perangkat nilai-niai sosial dan kebudayaan yang melingkupi. Pemahaman tersebut memberikan suatu perspektif pandangan bahwa persoalan komunikasi sebenarnya adalah juga persoalan kebudayaan. Artinya, penggunaan lambang-lambang atau simbol dalam proses jalinan interaksi di antara para pelibat (participants) merupakan unsur dari proses kebudayaan yang lebih besar.

Pandangan demikian membawa konsekuensi bahwa komunikasi merupakan perekat bagi para pihak yang terlibat dalam proses jalinan interaksi. Individu (atau mungkin kelompok) warga masyarakat Jawa menjalin interaksi dengan individua atau kelompok warga masyarakat Minangkabau atau mungkin dengan individua tau kelompok warga masyarakat Bugis untuk kepentingan atau urusan-urusan tertentu di samping dengan individu atau kelompok masyarakatJawasendiri.Dalamkonteksdemikian maka dapat dipahami arti penting dari kebiasaankebiasaan serta nilai-nilai sosial-budaya yang ada pada (atau dianut oleh) masing-masing warga masyarakat etnis bersangkutan termasuk gaya komunikasi (communication style). Kebudayaan merupakan suatu entitas yang dipelajari yang karena itu setiap orang menggunakan pengalaman dan nilai-nilai sosial-budaya masyarakat di dalam mana orang bersangkutan menjadi warganya sebagai acuan nilai dalam menjalin komunikasi dengan orang lain.

Hal demikian menguatkan pandangan bahwa perbedaan-perbedaan dalam latarbelakang kebudayaan memungkinkan adanya perbedaanperbedaan dalam gaya berkomunikasi; atau dengan kata lain kebudayaan membawa dampak pada gaya komunikasi. Terkait dengan hal ini Giri (2006) mengemukakan penegasan bahwa antara komunikasi dengan kebudayaan merupakan dua entitas yang saling berpengaruh satu terhadap yang lain atau mengutip kata-kata Giri: "Communication and cuture have a great influence on each other." Aadanya perbedaanperbedaan-perbedaan dalam gaya komunikasi di antara berbagai kelompok masyarakat disebabkan oleh perbedaan-perbedaan budaya.

Dalam literatur dan khazanah teori komunikasi konsep gaya komunikasi (communication style) sering dimaknai sebagai kecenderungan umum dalam berkomunikasi terutama komunikasi antar pribadi yang merupakan pola pengorganisasian hubungan interaksi dengan menggunakan lambanglambang bahasa verbal maupun nonverbal (Panisoara et.al, 2015; Norton, 1983; Klopf dan Cambara, 1981). Mencermati pemaknaan demikian maka dapat dikatakan bahwa konteks gaya komunikasi lebih terletak terutama pada komunikasi antar pribadi, terutama sekali yang berlangsung secara verbal dan teristimewa dalam jalinan komunikasi antar budaya.

Hall, Gudykunst, membahas cara pandang mengenai gaya komunikasi dengan menggolongkannya ke dalam dua kecenderungan umum yakni high context dan low context culture dengan berpijak pada 
keyakinan bahwa kebudayaan dapat dicermati melalui bentuk dan/atau sifat dari penyampaian pesan dalam jalinan komunikasi warga masyarakat (Yang, 2016). Gaya komunikasi high context ditandai antara lain oleh sifat atau kecenderungan berkata-kata dalam bahasa yang tidak langsung (indirect), penuh perasaan banyak melibatkan emotional intelligence, lebih banyak mengemukakan gambaran-gambaran atau alasan-alasan, dan kerapkali menggunakan diam (silence) sebagai bahasa; sementara gaya low context ditandai oleh sifat-sifat sebaliknya seperti cenderung lebih bersifat terbuka, langsung, dan menunjukkan posisi pendapat (contentious), dan kerapkali disertai upaya mempengaruhi (implisit ataupun eksplisit).

Mulkeen (2016) menawarkan contoh unsur atau aspek dari gaya komunikasi yang diyakininya sebagai konsekeunsi atau dampak dari kebudayaan yakni (a) kecenderunan dalam penggunaan kata benda atau kata kerja (nouniness and verbiness), (b) kecenderungan dalam penggunaan kalimat pasif ataukah kalimat aktif, dan (c) kecenderungan penggunaan cara pengutaraan gagasan secara langsung (direct, low context) ataukah tidak langsung (indirect, high context). Unsur yang dicontohkan oleh Mulkeen ini masih dapat diteruskan atau diperpanjang misalnya dengan menambahkan kemungkinan bagaimana kecenderungan umum diri berbeda posisi baik dalam hal pendapat, pandangan, data/informasi/fakta mengenai persoalan yang saling diperbincangkan, kecenderungan umum kata-kata yang digunakan ketika seseorang menemukan diri keliru atau salah, dan bagaimana kecenderungan umum kata-kata atau bahasa yang digunakan ketika seseorang menemukan bahwa orang lain dengan siapa dirinya menjalin komunikasi ternyata salah termasuk ketika ada orang lain (mungkin orang banyak) sedang ada bersamanya.

Bertolak dari latarbelakang itu, maka penelitian ini bertujuan untuk menganalisis kecenderungan persamaan dan perbedaan gaya komunikasi khususnya masyarakat Jawa, masyarakat Minangkabau, dan masyarakat Bugis. Alasan pemilihan ketiga kelompok masyarakat ini sebagai objek karena ketiganya adalah sama-sama tergolong masyarakat ras Melayu. Gaya komunikasi dicermati melalui empat aspek: (a) kecenderungan dalam penggunaan kata benda atau kata kerja (nouniness and verbiness), (b) penggunaan kalimat pasif atau aktif, (c) penggunaan cara pengutaraan gagasan secara langsung (direct) ataukah tidak langsung (indirect), (d) penggunaan kata-kata atau kalimat ketika mendapati diri berbeda posisi pendapat atau pandangan dengan orang lain yang menjadi partner berkomunikasi. Tambahan aspek terakhir menjadi kebaruan (novelty) dari penelitian ini.

\section{Metode Penelitian}

Penelitian ini menggunakan pendekatan kualitatif interpretif, bertolak dari filsafat fenomenologi yang memandang pengalaman, terutama sekali pengalaman dari orang pertama (pengalaman langsung dari pelaku yakni orangorang atau warga atau anggota masyarakat yang diamati) sebagai unsur pokok dari sumber pengetahuan (Bhattacherjee, 2012; Smith, 2013). Sebagaimana dikatakan Smith (2013), kata fenomenologi secara harfiah berarti studi mengenai gejala (phenomena) - yakni gejala yang menjadi objek penyelidikan. Smith mengatakan bahwa fenomenologi ".....studies conscious experience as experienced from the subjective or first person point of view." Paradigma konstruktivisme ini dipilih terutama karena penelitian ini pada dasarnya adalah penelitian mengenai manusia (masyarakat) dengan kebudayaannya yang unik - khususnya yakni gaya komunikasi di ketiga kelompok masyarakat atau budaya Jawa, Minang dan Bugis - yang memiliki perbedaan maupun kesamaan.

Metode studi kasus (case study) bersifat jamak (multiple-cases study) digunakan dalam penelitian ini untuk membandingkan tiga kasus yang berbeda yakni tiga kelompok masyarakat dengan kebudayaannya masing-masing: yakni masyarakat Minangkabau, masyarakat Jawa dan masyarakat Bugis. Gaya komunikasi ketiga kelompok masyarakat ini diteliti dan kemudian dibandingkan, diidentifikasi perbedaan serta persamaan yang ada dengan 
titik berat empat aspek sebagaimana sudah dikemukakan sebelumnya. Keunikan dari studi kasus sebagai suatu metode penelitian ilmiah, seperti dikatakan oleh Fidel (1983), adalah bahwa metode ini bersifat penelitian lapangan ini diarahkan secara khusus untuk mencermati gejala sebagaimana adanya tanpa ada intervensi yang signifikan dari peneiti. Perolehan dari metode ini terutama adalah untuk menghasilkan pemahaman yang komprehensif dan holistik mengenai gejala/kasus yang ditelti dan sekaligus juga menghasilkan proposisi ilmiah teoritis berkenaan dengan gejala-gejala yang dicermati.

Pengumpulan data dengan teknik wawancara mendalam (in-depth interview), observasi, dan pemanfaatan bahan-bahan dokumen dan literatur. Wawancara melibatkan 25 orang di ketiga kota: Padang (8 orang masyarakat Minangkabau), Surakarta atau Solo (10 orang masyarakat Jawa), dan Makassar (7 orang masyarakat Bugis). Informan diambil secara purposive terutama maximum variation sampling untuk masingmasing klompok masyarakat atau budaya, dengan mempertimbangkan latarbelakang sumber. Untuk kepentingan analisis dan validitas data, digunakan tehnik triangulasi terutama triangulasi sumber. Analisis dilakukan dengan melakukan reduksi data serta pengelompokan data berdasar kecenderungan atau tema; pemberian interpretasi terhadap kecenderungankecenderungan data untuk dapat dibuatkan kesimpulan mengacu pada tujuan penelitian.

\section{Hasil Penelitian dan Pembahasan}

\section{Gaya komunikasi masyarakat Minangkabau}

Secara geografis, masyarakat Minangkabau menempati wilayah budaya Minangkabau, tepatnya di Provinsi Sumatera Barat yang berpusat di Kota Padang. Masyarakat Minangkabau dikenal senang merantau. Masyarakat Minang sebenarnya kedapatan di seluruh penjuru negeri bahkan juga di luar negeri. Hasil penelitian menunjukkan bahwa:

\section{Kecenderungan penggunaan kata kerja - kata benda}

Secara umum dapat dikatakan bahwa dalam percakapan sehari-hari, warga masyarakat Minangkabau lebih sering menggunakan kata kerja dibandingkan dengan kata benda dalam memulai percakapan. Hal demikian terlihat dari percakapan dalam kehidupan sehari-hari seperti misalnya sebagai berikut: "Makanlah kue mangkuk itu, enaknya saat masih panas begitu". "Jangan mengikuti apa kata orang terus, yang punya hidup kita, ya kita yang tahu."

Dalam kaitan ini seorang sumber Ans. (54, L) menjelaskan bahwa pada dasarnya orang Minang memang lebih banyak menggunakan kata kerja dibanding dengan kata benda. Hal demikian disebabkan oleh karakter dari orang Minangkabau yang berpegang pada prinsip mengutamakan kontribusi untuk sesama di samping kenyataan bahwa orang Minang memiliki kebiasaan merantau dan berdagang. Lebih tepatnya Ans, menuturkan bahwa Orang Minang lebih banyak menggunakan kata kerja [terutama di bagian awal penuturan]; hal ini mungkin karena sifat orang Minang yang punya prinsip untuk berkontribusi dahulu baru mengharap imbalan kemudian; dan orang kita itu [orang Minang - pen.] suke mengayomi sesama. Kemudian kebiasaan merantau dan berdagang membuat orang Minang memiliki pola bertutur lebih banyak menggunakan kata kerja.

\section{Kecenderungan penggunaan kalimat aktif- pasif}

Hasil penelitian menunjukkan masyarakat Minangkabau lebih sering menggunakan kalimat aktif dibandingkan dengan kalimat pasif. Dapat dikatakan bahwa hal demikian merupakan konsekuensi dari lebih banyaknya penggunaan kata kerja dibanding dengan kata benda. Penggunaan kalimat aktif banyak sekali dijumpai dalam kalimat berita, termasuk yang menyangkut diri sendiri maupun orang atau sesuatu yang lain sebagai pokok kalimat. Penuturan dengan gaya 
demikian sangat lazim dijumpai di kalangan masyarakat Minang. Sebagai contoh, ketika seseorang menceriterakan bahwa dirinya sudah melamar pekerjaan ke sana dan ke mari termasuk melamar diperkebunankelapa sawitmaka kalimat yang digunakan kurang-lebih sebagai berikut:

"Sudah banyak saya melamar pekerjaan; ini di perkebunan sawit saya [juga] lamar; tapi ya itu harus siap di pelosok kampong. Kemaren anak-anak itu [mem]bantu ibu mengisi rapor yang setumpuk itu, untung ada yang mau bantu."

Lebih lanjut dalam kalimat ajakan atau menjawab pertanyaan ternyata kalimat aktif juga lebih sering digunakan. Seorang informan Dsr. (23 th.) menjelaskan hal ini dengan mengkaitkannya dengan kebiasaan-kebiasaan yang berkembang dalam masyarakat Minang. "Kalau untuk penggunaan kalimat aktif [ataukah] pasif itu sama saja - ya apa yang biasa dipakai itu yang diucapkan," demikian Dsr. menjelaskan.

\section{Kalimat Lansung atau Tidak Langsung}

Hasil penelitian menunjukkan bahwa masyarakat Minang cenderung memiliki gaya komunikasi tidak langsung (indirect). Hal demikian sangat erat terkait dengan kebiasaan berbalas pantun dalam masyarakat Minangkabau. Kecenderungan seperti ini memberikan isyarat bahwa bagi masyarakat Minangkabau, komunikasi merupakan suatu proses yang kompleks. Hal ini juga menandai sifat budaya Minang yang cenderung high context meminjam istilah Hall dan juga Gudykunst sebagaimana dikemukakan di bagian awal. Gaya komunikasi tidak langsung ini bagi masyarakat Minang dijumpai dalam beberapa bentuk termasuk pengibaratan, penghalusan dan juga sindiran.

Adr. (63 th. - pensiunan PNS) menjelaskan hal ini dengan menunjukkan sifat orang Minang yang suka mengutamakan kearifan sehingga kehati-hatian dalam berbicara merupakan hal yang sangat penting dalam jalinan hubungan dengan orang lain. Hal demikian tersosialisasikan secara turun-temurun sehinga mewarnai budaya
Masyarakat Minang. Pantun dan kemudian juga Gurindam merupakan bentuk-bentuk keindahan serta ketinggian budaya Minang dalam bertutur kata yang kesemuanya bersifat tidak langsug. Adr. kemudian menambahkan sebagai berikut.

Orang Minang itu arif dan bijaksana, punya perasaan yang mendalam, dan sangat menunjung tinggi adat dan sopan-santun. Karena ini maka orang Minang banyak memakaikiasan, cenderung tersamar atau mungkin menyindir supaya tidak ada kesan lansung [frontal] dan kasar. Orang Minang tau dengan kato nan ampek, yang kato malereang itu lah penerapan kiasan yang sebenarnya. Fer. (50 th. ), sejalan dengan Adr. menjelaskan hal tersebut dengan mengatakan:

Orang kita [orang Minang - pen.] kalau berbicara itu penuh akan isyarat, [tidak langsung - pen.] - jadi hati-hati kalau berbicara kepada orang lain, dan tidak bisa sembarangan saja. Orang Minang itu kan tau tenggang rasa, tau dengan [perasaan] malu.

\section{Respon Terhadap Perbedaan Pendapat}

Dalam percakapan sehari-hari, nampak kecenderungan bahwa masyarakat Minangkabau cenderung kuat dalam mempertahankan apa yang mereka yakini benar. Hal ini memengaruhi situasi komunikasi yang ada, seperti jika memiliki perbedaan pendapat dengan lawan bicara. Data yang berhasil dihimpun menunjukkan bahwa mempertahankan pendapat atau keyakinan (berargumen) sangat mewarnai jalinan komunikasi antar pribadi di kalangan warga masyarakat Minangkabau. Sepintas hal ini merupakan gejala paradoksal dengan yang sebelumnya dikatakan bahwa masyarakat Minang cenderung berhati-hati yang mengutamakan kearifan. Dalam konteks ini, sebagaimana nampak melalui banyak kenyataan, diarahkan untuk mencapai kesepakatan (kemufakatan); "Sebenarnya orang Minang itu bukannya tidak suka dengan si $\mathrm{X}$, tapi orang-orang yang ada dibelakangnya itu [orang-orang di belakang $\mathrm{X}$ ]; jadi si $\mathrm{X}$ bisa disuruh-suruh seperti pembantu saja (W, 21 th., mhsw)." 
W. (21 th.) menjelaskan hal ini dengan menunjuk tujuan berdebat yakni untuk mencari kebenaran untuk disepakati dan hal ini merupakan kebiasaan yang sudah lama terwariskan secara turun-temurun dari generasi ke generasi baik yang mengambil konteks adat (sambah kato) maupun konteks informal seperti di warung-warung (ota lapau). "Urang minang tu suko berdebat, berhujjah mancari suatu kebenaran atau kesepakatan, jadi kalau ado nan taraso alun sasuai, pasti disemba juo tu sampai ado kesepakatan baduo", demikian kata Adr.

\section{Gaya Komunikasi Masyarakat Jawa Kecenderungan Penggunaan Kata Kerja - Kata Benda}

Masyarakat Jawa, sangat mementingkan keseimbangan dan harmoni. Tidak mudah mengidentifikasi kecenderungan penggunaan kata benda dan kata kerja dalam jalinan komunikasi. Kendati demikian kalau harus dikatakan mana yang lebih sering digunakan antara kedua jenis kata tersebut maka ada kesan bahwa kata kerja, untuk berbagai konteks, lebih banyak digunakan. Hal ini terlihat dalam kalimat berita mengenai berapa lama waktu yang dibutuhkan untuk penyelesaian sebuah pekerjaan maka kalimat yang digunakan kurang lebih: "Butuh waktu tiga bulan untuk dapat menyelesaikan proyek itu", walau memang kalimat lain seperti: "Proyek itu butuh waktu tiga bulan untuk menyelesaikannya" juga sering digunakan. Berkenaan dengan hal ini seorang informanWd.(52 th.)mengatakansebagaiberikut:

"Orang Jawa memang suka bekerja keras; tetapi ada keseimbangan termasuk penghargaan terhadap materi (benda), bahkan juga hal-hal bersifat non-materi seperti kepuasan batin serta ekspresi penghambaan. Karena hal tersebut maka sesungguhnya agak sukar mengatakan segala sesuatu secara hitam-putih berkenaan dengan kebudayaan Jawa termasuk dalam hal gaya berkomunikasi”
Sejalan dengan Wd. Sumber lain Prt. (48 th.) mengatakan bahwa orang Jawa terutama di wilayah Solo dan Yogyakarta dan sekitarnya sangat memperhatikan partner berbicara dalam menjalin komunikasi termasuk kemungkinan perubahan wajah serta intonasi dan bahasa tubuh. "Karena hal demikian maka agak sulit sebenarnya mengatakan sesuatu bahwa orang Jawa begini atau begitu dalam berkomunikasi," demikian Prt. mengemukakan penjelasan.

"Walau demikian dala, banyak hal orang Jawa bisa menampakkan kejelasan dalam bersikap sehingga kecenderungan penggunaan kata kerja mungkin dapat dikatakan lebih menonjol dibandingkan dengan kata benda. Kalimat bernuansa perintah: 'Selesaikan dulu urusan itu, kemudian beritahu saya tentang perkembangnnya' nampaknya lebih lazim digunakan oleh orang Jawa dalam berkomunikasi dibandingkan misalnya dengan: 'Urusan itu selesaikan dulu, dan kemudian perkembangnnya beritahukan kepada saya,"

\section{Kecenderungan Penggunaan Kalimat Aktif- Pasif}

Tidak mudah membuat generalisasi mengenai kecenderungan masyarakat Jawa dalam menggunakan kalimat aktif ataukah pasif dalam percakapan sehari-hari. Seringkali warga masyarakat Jawa menggunakan kalimat aktif namun seringkali juga kalimat pasif juga lazim digunakan. Ada kesan bahwa perbedaan antara penggunaan kalimat aktif atau pasif tidak terlalu menyolok. Yang lebih menyolok sebenarnya adalah penggunaan kata-kata yang bersifat memperhalus (eufemisme) dan kalimat yang bersifat campuran antara bahasa Indonesia dengan bahasa Jawa. Dalam kehidupan seharihari, apabila terjadi perbincangan antara dua orang yang relatif sederajat maka kecenderungan penggunaan kalimat kurang lebih akan sebagai berikut: "Pak Lurah telah menyuruh orang untuk memperbaiki tanggul saluran yang jebol karena hujan semalam." Atau, dalam konteks 
atau urusan lain mungkin akan bernuansa sebagai berikut: "Pak Hadi meminta saya untuk menambah lagi persediaan semen supaya tidak terjadi keterlambatan dalam pengerjaan bangunan itu." Kedua kalimat sebagaimana baru saja dikemukakan tadi merupakan kalimat aktif. Kalimat pasif juga sangat lazim digunakan oleh orang Jawa dalam percakapan sehari-hari. Kalimat yang dimaksud misalnya sebagai berikut: "Pekan lalu saya diajak makan siang oleh Bu Halimah di rumah makan itu." Atau kalimat pasif lain seperti: "Nama itu sudah dimasukkan ke dalam daftar pemesan."

Terkait kalimat aktif-pasif, M. (60, L., pengamat budaya) menjelaskan agak panjang lebar sebagai berikut. Penggunaan kalimat aktif atau pasif agak bergantung pada siapa berkomunikasi dengan siapa. Kalau komunikasi berlangsung antara dua orang teman atau dua orang yang memiliki hubungan akrab maka kalimat aktif lebih sering digunakan; tetapi apabila tidak demikian maka kalimat pasif yang digunakan. Dengan demikian yang lebih sering digunakan adalah kata-kata, misalnya, "Ibu menyuruh saya ke sini untuk memberikan mangga ini," dan bukan "Saya disuruh Ibu ke sini untuk memberikan mangga ini." Tetapi apabila percakapan berlangsung di antara orang yang tidak begitu akrab atau percakapan dengan orang yang sangat dihormati maka hal sebaliknya yang terjadi. Hal demikian menandai sikap kehati-hatian menjalin hubungan komunikasi walau penggunaan kedua jenis kalimat tadi juga agak sumir [perbedaan kurang signifikan]. Yang lebih menyolok sebenarnya adalah penggunaan kata-kata bersifat eufemistik (menghaluskan) serta pilihan kata atau kalimat dalam tingkat halus (krama) sehingga seringkali, walau tidak selalu, terjadi penggunaan bahasa yang bersifat campuran antara bahasa Jawa halus dengan bahasa Indonesia seperti misalnya: "Inggih ... Bapak tinggal paring dhawuh saja" (Iya .... Bapak tinggal beri perintah kepada saya saja).

\section{Kalimat Langsung atau Tidak Langsung}

Hasil penelitian menunjukkan bahwa masyarakat Jawa lebih sering menggunakan kalimat tidak langsung dibandingkan dengan kalimat langsung. Penghargaan yang tinggi terhadap keseimbangan dan keharmonisan mengharuskan orang Jawa lebih cermat dalam mengemukakan pikiran dalam suatu jalinan komunikasi dengan orang lain. Di samping itu kecenderungan sikap rela mengalah demi tetap terjaminnya kebersamaan juga seringkali muncul dalam perbincangan dalam kehidupan seharihari. Hal-hal seperti pilihan kata (diksi) dan rumusan serta sifat kalimat yang digunakan dalam berkomunikasi sehari-hari biasanya diharapkan untuk tidak membuat orang lain menjadi tersinggung atau tersakiti hatinya, atau menjadi dipermalukan. Kalimat bersifat langsung lebih banyak dijumpai dalam kalimat perintah misalnya oleh orangtua kepada anak atau oleh majikan kepada buruh. M. (60, L, pengamat budaya) menjelaskan hal demikian sebagai berikut.

Kebudayaan masyarakat Jawa sangat kaya akan simbol. Karena itu di dalam berkomunikasi, termasuk bertutur, masyarakat Jawa lebih sering bersifat simbolik dan tidak bersifat langsung. Termasuk berkomunikasi tidak langsung adalah apa yang dikenal luas sebagai sindiran. Eufemisme [penghalusan makna] merupakan sebagian dari unsur membangun kalimat tidak langsung. Apabila hendak mengemukakan saran supaya seseorang [partner berkomunikasi - pen.] segera pergi atau pulang karena waktu sudah terlalu sore maka orang bersangkutan cenderung akan memilih kata-kata kurang lebih: "Iya ... hal ini mungkin dapat kita bicarakan lebih lanjut nanti;" dan bukan misalnya "Wah ... maaf sudah sore ini rupanya ya ... "

\section{Respon Terhadap Perbedaan Pendapat}

Hasil penelitian menunjukkan bahwa masyarakat Jawa sangat menghargai keseimbangan dan menjunjung tinggi harmoni termasuk yang berkaitan dengan jalinan hubungan dengan orang lain dan berkomunikasi. 
Orang Jawa seringkali mengalami kesulitan ketika harus mengambil sikap saat menyadari bahwa antara dirinya dengan partner berbicara memang terdapat perbedaan pendapat atau pandangan. Apa yang lebih sering terjadi ketika berkembang suasana demikian adalah sikap mengalah setelah mengingatkan dan/atau menyampaikan penegasan, misalnya dengan kata-kata "inggih sampun" (ya sudah - dalam nuansa lebih menghirmati), atau "luweh" (ya sudah, tapi resiko ditanggung sendiri - dalam nuansa lebih sederajat). Perdebatan sampai tingkat tertentu bisa terjadi apabila perbincangan menyangkut hal-hal yang bersifat prinsipiil; namun dalam banyak hal sepakat untuk tidak sepakat kerapkali terjadi. Berkenaan dengan hal ini Spt. (48, P, Guru) menjelaskan bahwa Orang Jawa pada umumnya meyakini bahwa kebersamaan merupakan hal yang utama dalam kehidupan bermasyarakat. Kebersamaan hanya bisa dibangun dengan kerelaan untuk mengalah dan berkorban sehingga tercipta keseimbangan dan harmoni. Perbedaan pendapat atau pandangan kadangkala memang dirasakan sebagai hal mengganggu. Karena itu tindakan mengingatkan atau mungkin mengajak merupakan hal penting dalam jalinan komunikasi untuk kebersamaan. Namun demikian apabila tidak dapat juga dicapai kesekatakan maka sikap melepaskan diri dari urusan kemudian menjadi pilihan sikap - yang biasanya disampaikan dengan kata-kata "inggih sampun' atau "luweh". Hal demikian merupakan sikap membiarkan diri masing-masing berada dalam keyakinan yang dipegangnya.

Sejalan dengan dengan Spt., Swd ( 60 , L, pensiunan) menguraikan hal tersebut sebagi berikut: "Selagi persoalan yang saling diperbincangkan tidak menyangkut pengambilan hak atau merendahkan martabat maka jarang sekali terjadi perdebatan yang berkepanjangan. Sikap mengalah namun dalam nuansa tidak mau ikutikutan merupakan kecenderungan umum dari orang Jawa apabila terjadi perbedaan pandangan dan upaya mencapai kesepakatan sudah tidak mungkin lagi dicapai”

\section{Gaya Komunikasi Masyarakat Bugis} Kecenderungan penggunaan kata kerja - kata benda

Orang Bugis sangat dikenal luas sebagai orang pemberani, mandiri, dan lugas. Kebiasaan mengarungi lautan serta tempaan cuaca panas serta deburan ombak membuat orang Bugis pada umumnyamemilikikarakterterbukadantakgentar menghadapi tantangan. Orang Bugis memiliki budaya siri (rasa malu terpaut terutama dengan haga diri). Budaya ini memiliki empat elemen utama: (a) ripakasiri (rasa malu berhubungan dengan harga diri secara pribadi), (b) mappakasiri (berhubungan dengan etos kerja), (c) tappela siri (berhubungan dengan tanggungjawab dan janji), dan (d) mate siri (berhubungan dengan keyakinan iman) (Azizah, 2014; Bitar, 2017).

Dengan latarbelakang sebagaimana baru saja dikemukakan maka berkenaan dengan gaya komunikasi khususnya terkait dengan penggunaan kata kerja dan kata benda, terdapat kesan bahwa orang Bugis cenderung lebih banyak menggunakan kata kerja dibandingkan dengan kata benda dalam percakapan seharihari. Hal demikian nampak misalnya ketika seseorang hendak menyatakan bahwa dirinya akan membawa makan siang ke tempat kerja maka orang bersangkutan cenderung menggunakan kalimat yang kurang lebih sebagai berikut: "Saya akan bawa makan siang ke kantor; tidak sarapan di rumah karena waktunya mepet sekali." Atau ketika seseorang merespon adanya undangan untuk hadir di suatu acara, misalnya pernikahan, maka orang bersangkutan akan menggunakan kalimat yang tersusun kurang lebih sebagai berikut: "Iya, terimakasih, ya. Kami akan datang Insya Allah. Sampaikan salam kami kepada beliau; dan katakan bahwa kami Insya Allah akan datang."

Seorang sumber atau informan Br. (54 th) mengatakan bahwa Orang Bugis memang lebih banyak menggunakan kata kerja dibandingkan dengan kata benda; karena orang Bugis adalah pekerja keras dan pantang menyerah. 
Orang Bugis bukan hanya terbuka tetapi juga pemberani. Lautan luas, ombak yang bergulung-gulung, dan udara yang panas; semua merupakan bagian dari kehidupan orang Bugis.

\section{Kecenderungan Penggunaan Kalimat Aktif- Pasif}

Hasil peneilitian menunjukkan bahwa warga masyarakat Bugis pada umumnya lebih banyak menggunakan kalimat aktif dibandingkan dengan kalimat pasif dalam percakapan seharihari. Hal demikian dapat dikatakan sebagai konsekuensi dari lebih seringnya digunakan kata kerja dibanding dengan kata benda. Kalimat sebagaimana dicontohkan di atas menguatkan pandangan demikian. Juga, contoh kalimat lain, ketika seseorang menceriterakan perihal bahwa titipan sudah disampaikan maka kalimat yang digunakan cenderung: "Sudah ki; saya sudah sampaikan itu titipan kemarin kepada beliau. Beliau yang menerima langsung."

Sn. (46 th.) ketika diwawancari mengenai hal ini menjelaskan panjang-lebar sebagai berikut.

"Kita orang Bugis mewarisi tradisi dan kebudayaan yang bersifat terbuka. Pekerjaan atau profesi sebagai pasompe (nelayanpedagang) membuat orang Bugis menjadi pemberani tetapi juga akomodatif terhadap perubahan tetapi sekaligus juga menjaga nilai-nilai kebudayaan atau adat kebiasaan yang menginspirasi ataumungkin mendorong perubahan. Bertemunya agama dengan adat kebiasaan merupakan contoh nyata untuk hal ini. Kota Makassar berkembang menjadi kota besar metropolitan, namun ajaran-ajaran agama Islam serta nilai-nilai tradisional juga terpelihara. Penyebutan seseorang dengan gelar kebangsawanan seperti puang atau karaeng tidak lagi sesering dulu digunakan, dan orang Bugis sekarang lebih menghargai prestasi dibandingkan dengan gelar yang diperoleh dari keturunan. Ini artinya orang Bugis lebih berkarakter aktif bukan pasif. Hal demikian berkonsekuensi kepada cara bertutur [gaya komunikasi - pen.] orang Bugis modern sekarang: terbuka dan banyak menggunakan kalimat aktif."

\section{Kalimat Langsung atau Tidak Langsung}

Data hasil penelitian menunjukkan bahwa masyarakat Bugis cenderung berbicara dengan kalimat langsung (direct) terutama apabila perbincangan menyangkut hal yang bersifat umum - menyangkut isu publik, persoalan setempat (lokal), dan kepentingan bersama serta urusan pekerjaan. Inilah sebabnya maka sering muncul anggapan yang bersifat stereotipik walau tidak selalu benar bahwa orang Bugis cenderung temparemen. Ada hal yang menarik dalam hubungan ini; yakni ketika perbincangan menyangkut urusan pribadi dan/atau hal sensitif maka biasanya kedua partisipan komunikasi cenderung saling menunggu, saling menjaga diri. Dalam kaitan ini nampaknya berlaku semacam dalil bahwa semakin sensitif isu/persoalan yang saling diperbincangkan maka akan semakin ketat pula partisipan komunikasi saling menjaga diri (bersikap hati-hati). Seperti dalam kutipan wawancara langsung yang dilakukan pada informan (R. 20 th., pemilik kedai kopi), "Saya mau bikin kedai kopi tapi sudah terlalu banyak di sini. Orang Makassar lebih pilih beli makanan ringan harga 30 ribu dari pada beli makanan berat seharga 30 ribu; itu riil. Target bisnis sebenarnya itu. Lihat Maichi itu; kenapa dia bisa laris seperti itu". Dari wawancara dapat dilihat bahwa kalimat yang disampaikan orang Bugis cenderung lugas, tegas, dan langsung pada inti permasalahan. Mereka menghindari penggunaan kalimat yang melingkar berbelit-belit atau menggunakan perumpamaandanbasa-basiyangberkepanjangan.

\section{Respon Terhadap Perbedaan Pendapat}

Penelitian ini menunjukkan bahwa penggunaan kalimat yang lebih sering dijumpai dalam bercakapan sehari-hari di kalangan masyarakat Bugis berkenaan dengan adanya perbedaan pendapat diwarnai oleh sifat kokoh dalam mempertahankan keyakinan. Bahkan apabilakomunikasi dilakukanoleh dua orangyang memiliki kelas sosial berbeda maka cenderung terjadi dominasi oleh orang dari kelas yang lebih 
tinggi terhadap kelas sosial yang lebih rendah. Hal ini memengaruhi situasi komunikasi yang ada, termasuk misalnya apabila ternyata terdapat perbedaan pendapat dengan partner berbicara. Partisipan komunikasi berasal dari kelas sosial yang sama maka, sebagaimana nampak dari observasi dan wawancara, terlihat bahwa ada kecenderungan untuk masing-masing partisipan mempertahankan pendapat dan/atau pandanganpandangannya sehingga terjadi semacam perdebatan. Seorang sumber Sn. (48, PNS) menjelaskan: Pada umumnya orang Bugis sangat menjunjung tinggi upaya pencarian kebenaran juga harkat dan kehormatan. Orang Bugis juga sangat menghormati para tokoh masyarakat dan pemuka agama. Karena itu maka orang Bugis kerapkali terlibat dalam diskusi yang diwarnai ketegangan dengan aksentuasi yang kuat apabila perbincangan menyangkut persoalan-persoalan penting menyangkut kehidupan bersama di antara sesama warga. Tetapi apabila ada orang yang diketahui luas berasal dari kalangan yang lebih terpandang terlibat dalam diskusi maka kecenderungan asimetris terjadi. Dalam situasi demikian maka partisipan dari kalangan kebanyakanlebih banyak mendengar. Halinilebih dikarenakan untuk pemberian penghormatan.

Hasil penelitian menunjukkan beberapa perbedaan bahwa masyarakat Minang merupakan kelompok masyarakat etnis tergolong 10 besar di Indonesia, secara adat kawasan huni masyarakat Minangkabau meliputi tiga daratan utama (disebut dalam bahasa Minang Luhak Nan Tigo) yaitu Luhak Agam (Kabupaten Agam dan Kota Bukittinggi), Luhak Tanah Data (Kabupaten Tanah Datar, Sijunjung, Padang Pariaman hingga Sawahlunto) dan Luhak Limo Puluah (Kabupaten Lima Puluh Kota dan Kota Payakumbuh). Banyak warga masyarakat Minangkabau menekuni sektor bisnis dan perdagangan. Banyak masyarakat Minang asli pergi merantau untuk mencari penghidupan yang lebih baik dan menjadi ajang berbakti kepada kampung-halaman. Masyarakat Minang sangat kuat berpegang pada adat; dan adat Minangkabau sejauh ini tetap kokoh terjaga oleh tiga pilar utama yang disebut dengan Tali nan Tigo Sapilin: Alim-ulama, cerdik-pandai, dan Ninik-mamak (Nasar, 2017; Anindya, 2014).

Hasil penelitian dan pembahasan memperlihatkan empat aspek penting gaya komunikasi: penggunaan kata benda dan kata kerja, penggunaan kalimat aktif dan kalimat pasif, penggunaan kalimat langsung atau tidak langsung, dan kecenderungan sikap ketika mendapati diri berbeda pendapat atau pandangan dengan orang lain.

\section{Simpulan}

Bertolak dari data hasil penelitian dan pembahasan, dapat disimpulkan bahwa, kendati masyarakat Minangkabau, masyarakat Jawa dan masyaraka Bugis sebenarnya tergolong ke dalam kelompok yang sama yakni masyarakat Melayu yang karenanya memiliki kesamaan-kesamaan di sana-sini dalam hal gaya komunikasi; namun demikian terdapat perbedaan-perbedaan sampai tingkat tertentu terkait dengan empat aspek penting gaya komunikasi: penggunaan kata benda dan kata kerja, penggunaan kalimat aktif dan kalimat pasif, penggunaan kalimat langsung atau tidak langsung, dan kecenderungan sikap ketika mendapati diri berbeda pendapat atau pandangan dengan orang lain.

Dalam hubungan ini orang Minangkabau terkesan lebih banyak menggunakan kata kerja, lebih banyak menggunakan kalimat aktif, lebih sering berbicara secara tidak langsung (indirect) - dalam arti kurang bersifat to the point, dan lebih memilih sikap menguji pendapat dengan berargumen sampai titik tertentu dengan partner berbicara untuk mencapai kebenaran, untuk mengingatkan satu dengan lain, dan untuk mencapai kesepakatan. Agak berbeda dengan orang Minang, gaya komunikasi orang Jawa cenderung ditandai oleh relatif keberimbangan dalam penggunaan kata kerja dan kata benda; begitu juga dalam hal penggunaan kalimat 
aktif dan pasif. Kemudian orang Jawa memiliki kemiripan dengan orang Minangkabau seringkali berbicara secara tidak langsung (indirect); namun dalam kaitan ini orang Jawa, berbeda dengan orang Minang dan orang Bugis. Demi tetap menjaga hubungan yang harmonis orang Jawa cenderung mengambil sikap hatihati dalam mengemukakan pendapat atau pandangan, dan apabila ternyata pendapat atau pandangannya berbeda dengan orang lain maka orang Jawa lebih sering mengambil sikap luweh yakni terserah kamu atau resiko tanggung sendiri (tidak mau ikut campur) - setelah mengemukakan pikirannya dan/atau mengingatkan secara lembut atau santun sampai tingkat tertentu, dan kurang suka berdebat. Sementara itu terdapat kesan bahwa gaya komunikasi orang Bugis lebih ditandai oleh kecenderungan penggunaan kata kerja dibanding kata benda - seperti halnya orang Minang, dan dalam tingkat yang lebih rendah juga sama dengan orang Jawa. Orang Bugis lebih banyak menggunakan kalimat aktif dan berbicara dalam sifat langsung (direct, langsung, to the point) - berbeda dengan yang lazim di kalangan masyarakat Minang dan Jawa. Kemudian seperti halnya warga masyarakat Minangkabau, orang Bugis kerapkali menunjukkan sifat terbuka dan cenderung menganggap penting beradu pendapat (berargumen) untuk mencapai kesepakatan atau kebenaran. Namun dalam hubungan ini sifat lugas dan berani lebih nampak di kalangan warga masyarakat Bugis.

Bertolak dari kesimpulan demikian maka selanjutnya dapat dikatakan bahwa nilai-nilai budaya yang berkembang di masing-masing masyarakat serta termasuk juga kebiasaankebiasaan berdampak pada gaya komunikasi. Masyarakat Minangkabau memiliki gaya komunikasi tersendiri - begitupun masyarakat Jawa dan juga masyarakat Bugi - hal demikian karena masing-masing dari tiga kelompok masyarakat ini memang memiliki kebudayaannya masing-masing. Kenyataan demikian membawa konsekuensi penguatan terhadap pandangan bahwa kebudayaan berpengaruh terhadap gaya komunikasi.

\section{Daftar Pustaka}

Azizah, Z. (2014). Sejarah dan Adat istiadat Suku Bugis Asal Sulawesi Selatan diakses dari http://dunia-kesenian.blogspot.co.id/ Bhattacherjee,A.(2012). SocialScienceResearch: Principles, Methods, and Practices. University of South Florida (USF) Tampa Library Open Acces Collections (http:// scholarcommons.usf.edu/oa_textbooks). Bitar. (2017). Suku Bugis: Sejarah, Adat istiadat, Kebudayaan, kesenian, Rumah Adat, Dan Bahasa Beserta Pakaian Adatnya Lengkap. Diakses dari http:// www.gurupendidika.co.id/suku-bugis-. Cloud, D. (2013). Definition of Culture in Anthropology: Charcteristics \& concept. Diakses dari https://study.com/ academy/lesson/definition-of-culture-inanthropology-characteristics-concept.html).

Fidel, R. (1983). The Case Study Method: A case study. Diakses dari http:// faculty.washington.edu/fidelr/ RayaPubs/TheCaseStudyMethod.pdf

Giri, Vinjai N. The Review of Communication. $6(1-2)$, 124-130.

Karell, Daniel. (2018). 4 Types of Communication Styles. Diakses dari https:// online.alvernia.edu/communication-styles/.

Klopf, Donald and Ronald Cambra. (1981). A Comparison of Communication Styles of Japanese and American College Students. Diakses dari https://www.jstage.jst.go.jp/ article/jaces1962/1981/20/1981_66/_pdf.

Koentjaraningrat. (1981). Kebudayaan Mentalitas dan Pembangunan. Jakarta: Penerbit PT Gramedia.

Mulkeen, Declan. (2016). "How Culture Impact the Way We Think and Speak". Diakses dari https://www.communicaid.com/ business-language-courses/blog/shiftingcultural-sensibilities-in-language-use/).

Nasar, Fuad. (2017). Mengapa Orang Minang Merantau? Diakses dari https:// fuadnasar.wordpress.com/2017/04/25/ mengapa-orang-minang-merantu/ 
Norton, (1983). Communicator style: Theory, applications, and measures. Beverly Hills, CA: Sage Publications. Panisoara, Georgeta, Cristina Sandu, IonOvidiu Panisoara, Nicoleta Duta. (2015). Comparative Study Regarding Communication Style of the Students." Procedia - Social and Behavior Sciences 186, 202 - 208. Diakses dari http:// creativecommob.org/licenses/by-nc-nd/4.0/.

Patel, Salma. (2015). The research paradigm - methodology, epistemology and ontology - explained in simple language. Diakses dari http://salmapatel. c o. uk/ac ad emia/the-researchparadigm-methodology-epistemolo:
Characteristics and concepthgy-andontology-explained-in-simple-language. Prinz, Jesse. 2011. "Culture and Cognitive Science" dalam Stanford Encyclopedia of Philosophy. https://plato. stanford.edu/entries/culture-cogsci/ Smith, David Woodruff. 2013. "Phenomenology" dalam Stanford Encyclopedia of Philosophy. Diakses dari https://plato. stanford.edu/entries/phenomenology/. Yang, Xiaoxu. The influence of high/low context culture on choice of communication media: students' media choice to communicate with professors in China and the United States." Electronic Theses and Dissertations, 2375. https://doi.org/10.18297/etd/2375 